\title{
Comparative Study About Mechanical Properties of Strutural Standard Concrete and Concrete with Addition of Vegetable Fibers
}

\author{
Carla Regina Ferreira ${ }^{a *}$, Sheron Stephany Tavares ${ }^{a}$, Bruno Henrique Moreira Ferreira ${ }^{a}$, \\ Amanda Martins Fernandes ${ }^{b}$, Sara Jane Gomes Fonseca ${ }^{a}$, Carlos Augusto de Souza Oliveira ${ }^{b}$, \\ Ricardo Luiz Perez Teixeira ${ }^{b}$, Leonardo Lúcio de Araújo Gouveia ${ }^{a}$ \\ ${ }^{a}$ Faculdade de Engenharia, Universidade do Estado de Minas Gerais, Av. Brasília, 1304, Baú. \\ 35930-314, João Monlevade, MG, Brazil

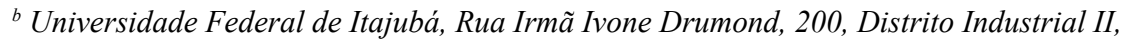 \\ 35903-087, Itabira, MG, Brazil
}

Received: December 1, 2016; Revised: April 7, 2017; Accepted: April 21, 2017

\begin{abstract}
This paper explored the effect of adding organic fibers from either bamboo or sugarcane on the mechanical properties of concrete. Cylindrical and prismatic specimens were made containing $2 \%$ and $5 \% \mathrm{v} / \mathrm{w}$ (volume to weight) of vegetable fibers to concrete. Following 28 days of curing period, the samples were evaluated for compressive strength, tensile strength using diametric compression, tensile strength during bending and static modulus. It was discovered that all concretes produced met the minimum strength of $20 \mathrm{MPa}$ recommended by NBR 6118 for structural purposes, and it was observed an increase of the compressive strength on the specimens with addition of organic fibers. Moreover, an increase in the compressive strength was observed in the specimens with fiber addition, although no significant variation of water absorption was noticed when compared with the standard concrete. In conclusion, the concrete containing $2 \% \mathrm{v} / \mathrm{w}$ of bamboo fibers showed better mechanical strength and static modulus of elasticity when compared to both concrete with sugar cane fibers addition and the concrete without any additional fibers.
\end{abstract}

Keywords: Concrete, Fiber, Mechanical properties, Civil construction

\section{Introduction}

Concrete is the most commonly material applied in civil construction. It is usually composed of cement, small aggregate, large aggregate, water and eventually chemical additives and additions, as Watts explains ${ }^{1}$. Over the years, the concrete has been improved and the use of vegetable fibers as a reinforcement of the cement matrix is an example.

The main advantages about using reinforced concrete with vegetable fibers (CRFV) come from the low cost of obtaining it and its characteristics are proper to the use as reinforcement of fragile materials, affirms Mostafa and Uddin $^{2}$. Another important aspect about applying CRFV is that they are renewable natural resources, and therefore do not degrade the environment.

For $\mathrm{Lee}^{3}$, the addition of fibers to the blend is an efficient way to increase concrete 's tensile strength, impact, fatigue, improve toughness and ductility. According to Lee, Cho and $\mathrm{Choi}^{4}$, the fibers do not prevent the formation of cracks in the composites, but, they are able to increase the tensile strength by controlling the propagation of cracks.

When the first crack appears in a concrete without the addition of fibers, its progressive opening causes the matrix to collapse. However, in composites with fibers, this fracture

* e-mail: carlaregina_metal@yahoo.com.br is delayed. The rupture becomes a progressive process, for the transfer bridges formed by the fibers absorb part of the requests and result to a more distributed cracking.

Figure 1 above shows the representation of a crack which is crossing a composite reinforced with fibers ${ }^{5}$, wherein: number (1) represents a ruptured fiber; (2) represents a stripped fiber; while (3) represents an intrinsic fiber through the crack. The fiber in (2) is an example where the fiber slides from the matrix. In (3), it is integral, partially absorbing the energy which the material is submitted.

The use of vegetable fibers as a reinforcing material to concrete has proved beneficial in many aspects, however, it is necessary to consolidate this study. The aim of this work was to evaluate the influence of the addition of bamboo and sugarcane fibers on the mechanical properties of concrete through compression, diametric compression, flexural/ bending tensile and elasticity module.

\section{Material and Methods}

\subsection{Materials used}

For doing this experiment, cylindrical and prismatic concrete specimens were produced and all the inputs applied 


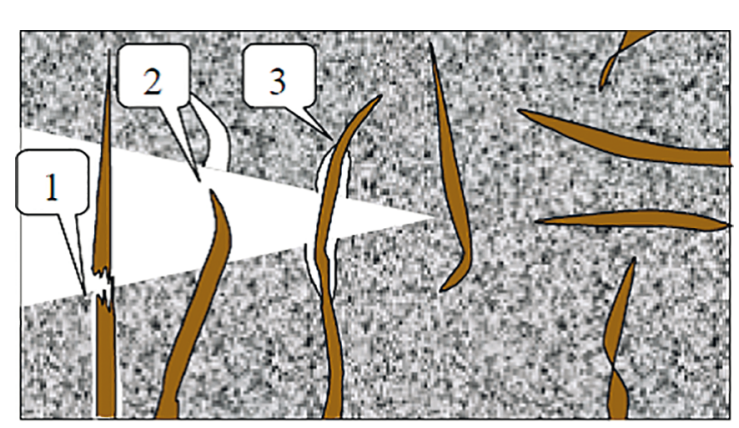

Figure 1. Schematic representation of a crack through a fiberreinforced composite.

in the specimens were characterized. The materials used for the practical tests of this paper are explained in the texts that follow.

\subsubsection{Portland cement}

The Portland pozolanic cement CP-IV 32 RS was used, according to NBR $5736^{6}$. Table 1 shows the physical requirements of the binder used in the concrete mixtures?

\subsubsection{Sand}

The quartz sand used in this study came from the Rio Piracicaba-MG. Table 2 shows the granulometric analysis of the small aggregate.

According to granulometric's analysis performed, the small aggregate presents maximum dimension characteristic of $1.2 \mathrm{~mm}$ and fineness modulus equal to 1.86 .

Other characterization tests of small aggregate showed that it has a specific mass of $2660 \mathrm{Kg} / \mathrm{m}^{3}$ and an apparent specific mass of $1385 \mathrm{Kg} / \mathrm{m}^{3}$.

\subsubsection{Gravel}

The large aggregate used in this experiment was a metamorphic origin (gneissite), Table 3 shows the characterization of this material.

According to results presented in Table 3 , the maximum characteristic size of gravel used in this research was $25 \mathrm{~mm}^{8}$. In addition, the aggregate has an absolute specific mass of $2668 \mathrm{~kg} / \mathrm{m}^{3}$ and an apparent specific mass of $1356 \mathrm{~kg} / \mathrm{m}^{3}$.
Table 2. Sand granulometric analysis.

\begin{tabular}{lcccccc}
\hline \multicolumn{7}{c}{ GRANULOMETRY } \\
\cline { 1 - 5 } $\begin{array}{l}\text { ABNT } \\
\text { sieve } \\
(\mathrm{mm})\end{array}$ & $\begin{array}{l}\text { Retained } \\
\text { mass }(\mathrm{g})\end{array}$ & \multicolumn{3}{c}{ \% individual retained } & $\begin{array}{c}\text { \% retained } \\
\text { accumulated }\end{array}$ \\
\cline { 2 - 6 } 4.8 & 0.0 & 0.0 & 0.0 & 0.0 & 0 & 0 \\
2.4 & 0.5 & 0.8 & 0.1 & 0.2 & 0 & 0 \\
1.2 & 19.5 & 17.3 & 5.3 & 4.8 & 5 & 5 \\
0.6 & 69.8 & 67.9 & 19.1 & 18.8 & 19 & 24 \\
0.3 & 149.6 & 146.4 & 48.8 & 40.6 & 45 & 65 \\
0.15 & 98.3 & 99.2 & 26.8 & 27.5 & 27 & 92 \\
Bottom & 28.7 & 29.2 & 7.9 & 8.1 & 8 & 100 \\
Total & 366.4 & 360.8 & $100 \%$ & $100 \%$ & $100 \%$ & \\
\hline
\end{tabular}

Table 3. Gravel granulometric analysis.

\begin{tabular}{lcccccc}
\hline \multicolumn{7}{c}{ GRANULOMETRY } \\
\cline { 1 - 5 } $\begin{array}{l}\text { ABNT } \\
\text { sieve } \\
(\mathrm{mm})\end{array}$ & $\begin{array}{c}\text { Retained } \\
\text { mass }(\mathrm{g})\end{array}$ & \multicolumn{3}{c}{ \% individual retained } & $\begin{array}{c}\text { \% retained } \\
\text { accumulated }\end{array}$ \\
\cline { 2 - 6 } 25,4 & 0.0 & 0.0 & 0.0 & 0.0 & 0 & 0 \\
19 & 387.3 & 346.0 & 7.8 & 7.0 & 7 & 7 \\
12.5 & 3860.0 & 3466.00 & 77.2 & 69.4 & 74 & 81 \\
9.6 & 686.3 & 1130.0 & 13.7 & 22.6 & 18 & 99 \\
6.3 & 58.8 & 49.0 & 1.2 & 1.0 & 1 & 1 \\
Bottom & 7.6 & 9.0 & 0.1 & 0.2 & 0 & 100 \\
Total & 5000.0 & 5000.0 & $100 \%$ & $100 \%$ & $100 \%$ & \\
Total & 366.4 & 360.8 & $100 \%$ & $100 \%$ & $100 \%$ & \\
\hline
\end{tabular}

\subsubsection{Fibers}

The fibers used in this work were bamboo and sugar cane. Before being incorporated into the concrete they were washed with tap water and dried at $100^{\circ} \mathrm{C}$ for 24 hours. The bamboo fibers had an average length of $4.5 \mathrm{~cm}$, while sugar cane had $3.5 \mathrm{~cm}$. Figure 2 shows the fibers after being washed and dried.

\subsubsection{Additive}

Additives are chemicals products that are added to cement or concrete to modify one or more properties of cementitious mixtures. In this experiment was used hyperplasticizer

Table 1. Cement's characterization.

\begin{tabular}{|c|c|c|c|c|c|c|c|c|c|c|c|c|}
\hline \multirow[b]{2}{*}{$\begin{array}{l}\text { Type of } \\
\text { Portland`s } \\
\text { cement }\end{array}$} & \multirow[b]{2}{*}{ Class } & \multicolumn{2}{|c|}{ Fineness } & \multicolumn{2}{|c|}{ Handle times } & \multicolumn{2}{|c|}{ Expandability } & \multicolumn{5}{|c|}{ Compressive strength } \\
\hline & & $\begin{array}{l}\text { Residue in } \\
\text { the } 75 \mathrm{~mm} \\
\text { sieve }(\%)\end{array}$ & $\begin{array}{l}\text { Specific } \\
\text { area } \\
\left(\mathrm{m}^{2} / \mathrm{Kg}\right)\end{array}$ & $\begin{array}{l}\text { Beginning } \\
\text { (h) }\end{array}$ & $\begin{array}{l}\text { End } \\
\text { (h) }\end{array}$ & $\begin{array}{l}\text { Cold } \\
\text { work } \\
(\mathrm{mm})\end{array}$ & $\begin{array}{c}\text { Hot } \\
\text { work } \\
(\mathrm{mm})\end{array}$ & $\begin{array}{l}1 \text { day } \\
(\mathrm{MPa})\end{array}$ & $\begin{array}{l}3 \text { days } \\
(\mathrm{MPa})\end{array}$ & $\begin{array}{l}7 \text { days } \\
(\mathrm{MPa})\end{array}$ & $\begin{array}{c}28 \\
\text { days } \\
(\mathrm{MPa})\end{array}$ & $\begin{array}{c}91 \\
\text { days } \\
(\mathrm{MPa})\end{array}$ \\
\hline \multirow{2}{*}{ CP IV } & 25 & \multirow{2}{*}{$\leq 8$} & \multirow{2}{*}{-} & \multirow{2}{*}{$\geq 1$} & \multirow{2}{*}{$\leq 12$} & \multirow{2}{*}{$\leq 5$} & \multirow{2}{*}{$\leq 5$} & \multirow{2}{*}{-} & $\geq 8.0$ & $\geq 15.0$ & $\geq 25.0$ & $\geq 32.0$ \\
\hline & 32 & & & & & & & & $\geq 10.0$ & $\geq 20.0$ & $\geq 32.0$ & $\geq 40.0$ \\
\hline
\end{tabular}




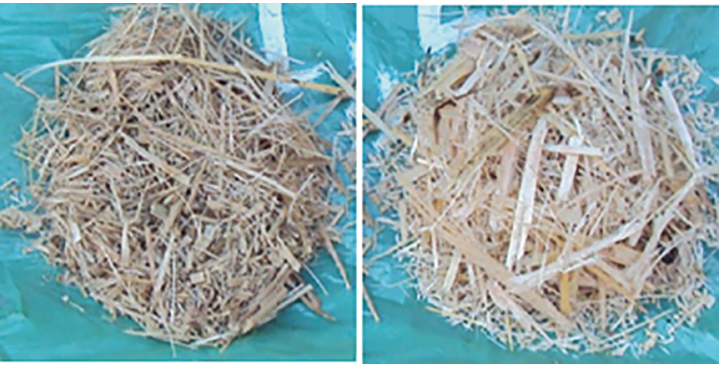

Figure 2. Plant fibers of bamboo and sugarcane respectively.

VEDACIT to guarantee the workability of the concrete when the fibers were added.

\subsection{Preparation of concrete and molding of specimens}

In order to study the behavior of the mechanical strength properties of reinforced concrete with vegetable fibers, $2 \%$ and $5 \%$ of bamboo and sugar cane fibers were added to the concrete mass. For the calculation of the trace, the water cement ratio was 0.56 , however, the addition of the hyperplasticizer additive interferes in this ratio, then the new ratio became 0.45 for all mixtures. The trace of Portland cement (c), fine aggregate (a), coarse aggregate (b) and water/cement ratio (is this order) is presented below:

\section{1: $1.73: 3.34: 0.45$}

The concrete's preparation was performed by using a free-fall concrete mixer, the vegetable fibers were the last inputs to be added in the mixture. Table 4 shows the characteristics of the traces. As can be observed, the unique modification made was the addition of fiber.

Subsequently, 50 cylindrical specimens were produced in the dimensions of $10 \mathrm{~cm}$ in diameter by $20 \mathrm{~cm}$ in height, as well as 15 prismatic specimens with a section of $4 \mathrm{~cm} \mathrm{x}$ $4 \mathrm{~cm}$ and a length of $16 \mathrm{~cm}$, as shown in Figure 3.

\subsection{Mechanical tests}

The mechanical properties evaluations of the reinforced concrete with vegetable fibers were obtained through the compressive strength test; Tensile strength in flexion; Tensile strength by diametrical compression and static modulus of elasticity. For all the tests, 28-days old specimens were used.

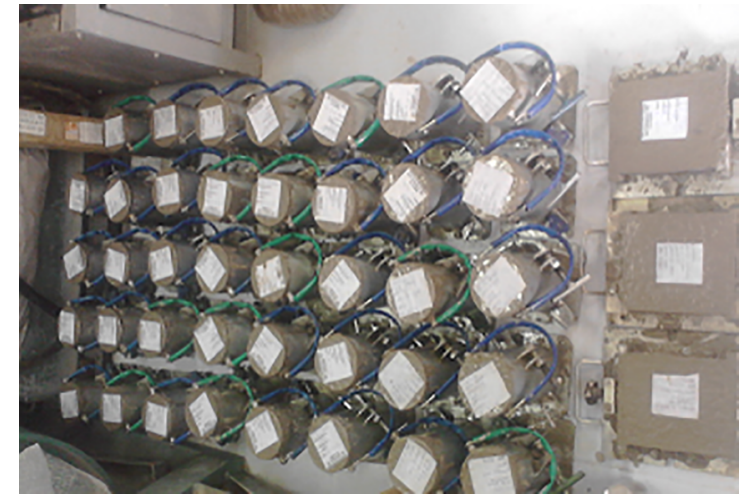

Figure 3. Specimens.

\subsubsection{Compressive strength}

The axial compression test consists of determining the maximum load of rupture supported by the specimen. For the accomplishment of this mechanical test, 3 test specimens of each type of concrete used in this study were tested. This assay followed NBR $5739^{9}$.

\subsubsection{Tensile strength by diametral compression}

This test is determined by the action of two diametrically opposed linearly distributed compression forces. These actions are provided by a mechanical press, creating a uniform tensile stresses perpendicular to the diameter of the specimen along the requested diameter. The forces are applied until the rupture of the specimen by indirect traction. This test followed NBR $7222^{10}$, and 4 test specimens of each concrete under study were tested.

\subsubsection{Tensile strength in bending}

In order to perform this test, a prismatic section specimen is submitted to bending, with loading in two symmetrical sections, until rupture. The test is determined by NBR 12142/MB 3483: ABNT" and is also known as "loading in the thirds", because the loaded sections meet in the thirds of the gap. A total of 3 specimens of each concrete type manufactured following NBR $121422^{11}$ were tested using the flexural tensile strength test.

Table 4. Trace Characteristics.

\begin{tabular}{lcccc}
\hline \multirow{2}{*}{ Concrete mixer } & \multicolumn{2}{c}{ TRACE } & ADDITION & \multirow{2}{*}{ AGE TEST } \\
\cline { 2 - 4 } & (c: $\mathrm{a}: \mathrm{b}:) \mathrm{Kg}$ & Fibers $(\mathrm{g})$ & Additive $(\mathrm{ml})$ & 28 days \\
\hline 0\% fiber & $6.2: 10.69: 20.67$ & 0 & 17.36 & 28 days \\
2\% bamboo & $6.2: 10.69: 20.67$ & 22.5 & 17.36 & 28 days \\
$5 \%$ bamboo & $6.2: 10.69: 20.67$ & 56.3 & 17.36 & 28 days \\
2\% sugarcane & $6.2: 10.69: 20.67$ & 28.4 & 17.36 & 28 days \\
$5 \%$ sugarcane & $6.2: 10.69: 20.67$ & 71.03 & 17.36 & \\
\hline
\end{tabular}




\subsubsection{Static modulus of elasticity}

The modulus of elasticity is the ratio between applied stress and strain below a proportional limit adopted. The static strain modulus for a concrete under axial compression is determined from the slope of the strain-strain curve obtained in cylindrical specimen tests. This assay followed NBR $8522^{12}$. For the mechanical test of the static elastic modulus, 3 specimens of each type of concrete were used.

\subsection{Water absorption test}

The water absorption test was done by immersion at atmospheric pressure according to LNEC-E394 specification ${ }^{13}$. To perform this test, it was used three standard concrete specimens, three with $2 \%$ of sugarcane fibers, three with $5 \%$ of sugarcane fibers, three with $2 \%$ of bamboo fibers and three with $5 \%$ of bamboo fiber totalizing 15 prismatic specimens, which were taken to the oven at $100{ }^{\circ} \mathrm{C}$ for a period of 24 hours. After this period, they were weighed. On the next day the specimens were placed in a vessel where water was added therein to about $1 / 3$ of the height of the specimens and this procedure was performed every 4 hours until they were covered up. On the following day, after a brief "trickle" to remove excess of water, the specimens were weighed to determine the amount of water absorbed.

\section{Results and Discussion}

In this topic, the results obtained through the resistance tests that were mentioned previously are presented. These data allow the evaluation of the resistance properties of the concrete reinforced with bamboo and sugarcane fibers.

The Figure 4 shows data for the axial compression test. It can be observed that the block of concrete without addition of fibers got the lowest value of compressive strength, and the concrete with addition of $2 \% \mathrm{v} / \mathrm{w}$ of bamboo presented the highest value. It is important to note that all reinforced concretes obtained better performance in the test when compared to standard concrete.

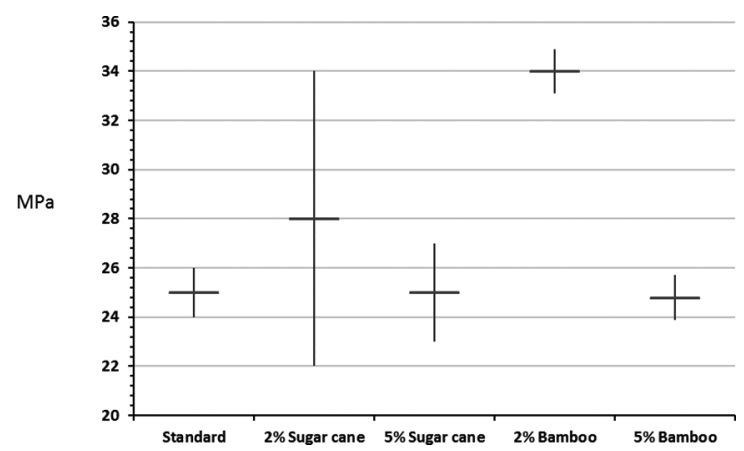

Figure 4. Data from the axial compressive strength test.
The Figure 5 shows the results for the tensile strength test by diametrical compression. It can be observed that, also in this test, the concrete without fibers addition presented the lowest resistance value, and the highest value occurred in the concrete with addition of $2 \% \mathrm{v} / \mathrm{w}$ of bamboo. The mechanical behavior of all concretes with fiber addition was higher than the standard structural concrete.

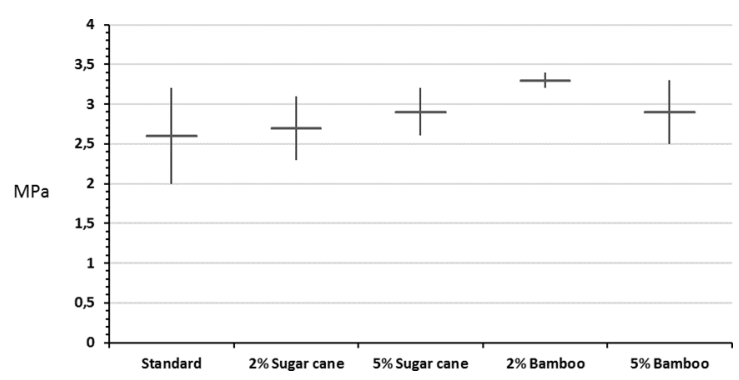

Figure 5. Data from the tensile strength test by diametrical compression.

It can be observed in Figure 6 (Flexural tensile strength) that the lowest result was obtained in the concrete without fibers addition, and the highest value was obtained in the concrete containing $5 \% \mathrm{v} / \mathrm{w}$ of sugar cane fiber.

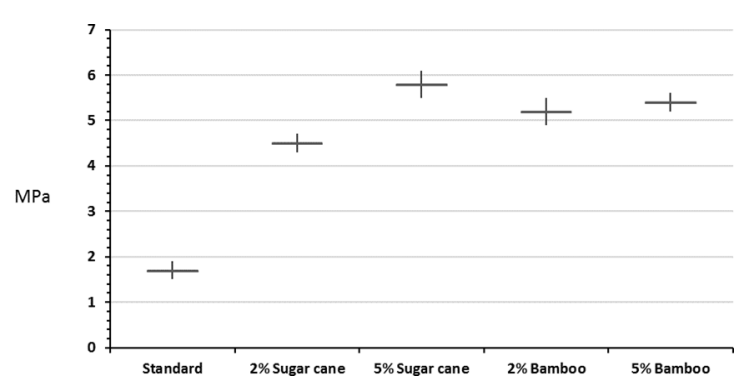

Figure 6. Data from the flexural tensile strength test.

The Figure 7 shows the results referent to the Modulus of Elasticity. It is possible to observe that the values are quite equivalent. The greatest value of modulus of elasticity occurred in the concrete containing $2 \%$ of bamboo fiber, and the lowest was in the concrete with $5 \%$ of sugar cane.

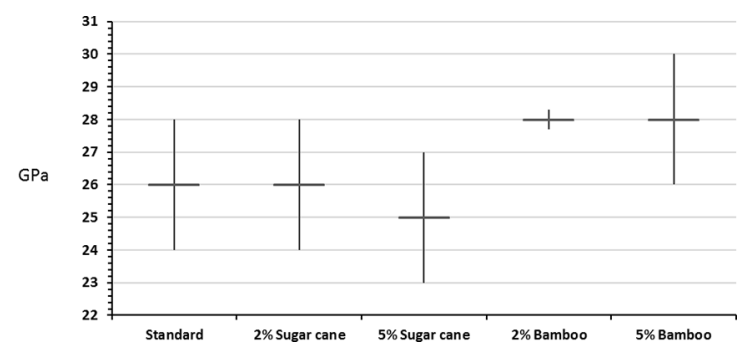

Figure 7. Data of static modulus of elasticity. 
Related to standard concrete, it is possible to affirm from the tests performed that the addition of sugar cane fiber reduced the hardness of the concrete, however the bamboo fiber increased the hardness of the material.

The Figure 8 shows the percentages results of the water absorption test. It is possible to note that the values are equivalent and there was no significant variation among the percentages obtained when compared to water absorption by the standard concrete.

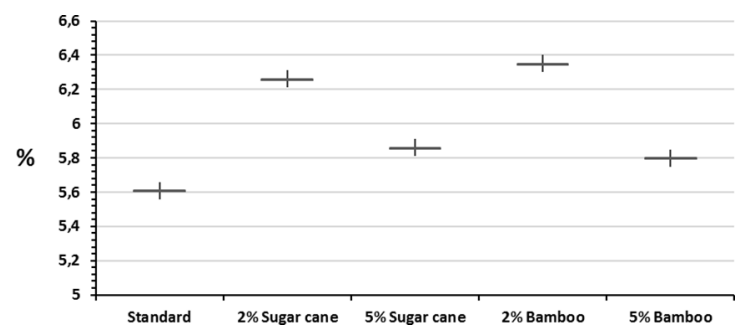

Figure 8. Data from the water absorption test.

\section{Conclusion}

According to the tests carried out, the use of vegetable fibers in concrete formulation is technically feasible. All concretes produced and tested met the minimum compressive strength of $20 \mathrm{MPa}$, established by NBR $6118^{14}$.

In the axial compression test, the concrete containing $2 \% \mathrm{v} / \mathrm{w}$ of bamboo presented an increase of $41 \%$ over to the standard concrete and $21.6 \%$ in relation to the same dosage with sugarcane. The same concrete also showed a better performance in the tensile strength test by diametrical compression. However, in the flexural tensile test, the concrete with $5 \%$ of sugarcane was the one that presented the best result, having an increase of $247 \%$ over to the standard concrete and $7 \%$ in relation to the same dosage with bamboo. Regarding the modulus of elasticity test, the concrete with addition of sugar cane fibers had a slight decrease in its stiffness, unlike the bamboo dosages, which had a slight increase. However, the values obtained were close to the standard, without a significant variation. Referring to the physical test of water absorption, the variation between the standard concrete and the concrete with addition of the vegetable fibers was less than $1 \%$, it is concluded that the addition of fibers does not implicate the performance of the concrete when working.

From the results obtained, the application of organic fibers has a lot of benefits, because the standard concrete presents low tensile strength. The addition of fiber provides an improvement of this property, since its function is to cross the fissures that might be formed in standard concrete, providing ductility in the middle of the fissures, therefore avoiding its spread. In order to obtain the expected result, the fibers must be well adhered in the matrix, it also must be in proper quantity. Within the percentages proposed, the most recommended is $2 \%$, which is the one that holds the best results.

It is interesting to test other types of fibers such as coconut, or sisal, in order to have an in-depth analysis of economic viability and also aiming the reuse of raw material. Previous studies have shown that either, bamboo or sugarcane, have good mechanical properties and high availability in countries like Brazil. Furthermore, it is recommended a deep study in the properties of each vegetable fiber presented, as well as the study of the durability of the concrete with addition of them, since the fibers can degrade with time. It is also recommended the study of some treatment to be applied under the fibers, before being added to the concrete. In the case of addition of fibers that was only washed and dried, it is also recommended the study of the possible attack of insects to the concrete, since the fibers can contain residues of starch and sugars.

\section{Acknowledgment}

This research was supported by FAPEMIG, MATCIMEUNIFEI, UNIFEI and UEMG.

\section{References}

1. Watts A. Modern Construction Handbook. Basel: Birkhäuser; 2016.

2. Mostafa M, Uddin N. Experimental analysis of Compressed Earth Block (CEB) with banana fibers resisting flexural and compression forces. Case Studies in Construction Materials. 2016;5:53-63.

3. Lee JH. Influence of concrete strength combined with fiber content in the residual flexural strengths of fiber reinforced concrete. Composite Structures. 2017;168:216-225.

4. Lee JH, Cho B, Choi E. Flexural capacity of fiber reinforced concrete with a consideration of concrete strength and fiber content. Construction and Building Materials. 2017;138:222-231.

5. Coutts RSP. "Sticks and stones...!!” CSIRO Forest Products Newsletter. 1986;2(1).

6. Brazilian Association for Technical Norms (ABNT). NBR 5736: Pozolanic Portland Cement - Specification (In Portuguese). Rio de Janeiro: ABNT; 1991.

7. Brazilian Association of Portland Cement (ABCP). Technical Bulletin: Basic guide to using Portland cement. (In Portuguese). São Paulo: ABCP; 2002.

8. Tavares SS, Teixeira RLP, Gouveia LLA, Ferreira BHM, Oliveira CAS, Ferreira CR. Comparative study of the mechanical properties of the concrete without addition of fibers and concrete with addition of vegetable fibers. In: $6^{9^{\text {th }}}$ International Anual Congress of ABM: 69; 2014 Jun 21-25; São Paulo, SP, Brazil.

9. Brazilian Association for Technical Norms (ABNT). NBR 5739: Concrete - Compression tests on cylindrical specimens (in Portuguese). Rio de Janeiro: ABNT; 2007. 
10. Brazilian Association for Technical Norms (ABNT). NBR 7222: Concrete and mortar - Determination of tensile strength by diametrical compression of cylindrical specimens (in Portuguese). Rio de Janeiro: ABNT; 2011.

11. Brazilian Association for Technical Norms (ABNT). NBR 12142/MB 3483: Concrete - Determination of tensile strength in flexion in prismatic specimens. (Procedure) (in Portuguese). Rio de Janeiro: ABNT; 1991.

12. Brazilian Association for Technical Norms (ABNT). NBR 8522: Concrete - Determination of the static modulus of elasticity to compression and strain-strain diagram - Test Method (in Portuguese). Rio de Janeiro: ABNT; 2008.

13. National Laboratory in Civil Engineering. LNEC E394: Concrete- Determination of Water Absorption by Immersion - Testing at Atmospheric Pressure (in Portuguese). Lisboa: National Laboratory in Civil Engineering; 1993.

14. Brazilian Association for Technical Norms (ABNT). NBR 6118: Design of concrete structures - Procedure (in Portuguese). Rio de Janeiro: ABNT; 2003. 